\title{
Analyzing the disaster response competency of the local government official and the elected representative in Nepal
}

\author{
Shrijan Bahadur Malla ${ }^{1,2^{*}}$, Ranjan Kumar Dahal ${ }^{3,4,5,6}$ and Shuichi Hasegawa ${ }^{7}$
}

\begin{abstract}
Local authorities i.e. government officials working at the district level and below and elected representatives of municipalities are the steering body of local-level disaster response mechanism in Nepal. The effectiveness of response operation moreover depends on their competency. This paper investigates their disaster response knowledge, preparedness, and perception, and to identify gaps and suggest recommendations.

The prevailing competency of Nepalese local authorities doesn't warrant an effective response during the time of disaster. They lack awareness and preparedness. Amidst their positive perception towards the need of disaster response capacity building, in the void of an effective mechanism, the government has failed to enhance their competency.

The national investment for disaster response competency building is meager in Nepal. The country heavily relies on foreign aid. The present capacity-building mechanism should be redressed from the newer dynamic.
\end{abstract}

Keywords: Disaster response, Government official, Elected representative, Knowledge, Preparedness, Perception, Training

\section{Introduction}

Today, effective disaster response has become a biggest challenge to the governments of the world. Research has proven that a centralized governance system is not suitable for effective disaster response (Daly et al. 2017). The 2005-2015 Hyogo Framework for Action (HFA) and 2015-2030 Sendai Framework for Disaster Risk Reduction have also reaffirmed the need of decentralized approach for effective disaster response (UNISDR 2005; UNISDR 2015). Centralized government's rigid bureaucratic framework, organizational hierarchy, and politicized budget and accountability mechanism is unsupportive for the venture especially at mega-disaster (Miller and Douglass 2016).

\footnotetext{
* Correspondence: shrijan7malla@hotmail.com

'Graduate School of Engineering, Kagawa University, 2217-20 Hayashi-cho, Takamatsu, Kagawa 761-0396, Japan

${ }^{2}$ Budhanilkantha Municiaplity, Ward No. 1, Kathmandu, Nepal

Full list of author information is available at the end of the article
}

Since disaster response is a bottom up approach, local level disaster response mechanism is the fundamental pillar for decentralization. As local authority and the local community should respond immediately to a disaster their effectiveness is crucial. In that sense, their competency plays critical role to save lives and properties at the time of disaster.

Today, Nepal is amongst the most disaster prone countries in the world. It ranks 4th and 11th in terms of climate change vulnerability and earthquake vulnerability respectively and 20th in terms of multi hazard vulnerable country in the world (UNDRR 2019; MoHA 2018a, 2018b). Basically the country's complex geographic location, diverse topography and highly varying climatic condition are the reasons for the geological and hydro-meteorological disasters. The situation has been further deteriorated by the unplanned development 
work, uncontrolled population growth, and increasing poverty. Precisely earthquake, landslide, flood, inundation, glacial lake outburst flood (GLOF), cold wave, heat wave, windstorms and hailstorms have been the reasons for killing more than 500 people every year in the country (MoHA 2015, 2018a, 2018b). Unfortunately, at present, more than $80 \%$ of the total population of the country is living under the risk of disaster (MoHA 2018a, 2018b).

The country's local level disaster response is relied at large on the capacity of the local level authority that comprises of the government officials and elected representatives functioning at district and municipality level. Since they are the members of the District Disaster Management Committee (DDMC) and Local Disaster Response Committee (LDMC), the local level response mechanisms, The Disaster Risk Reduction and Management Act 2017 has mandated them to remain crucial at the time of disaster (The Disaster Risk Reduction and Management Act 2017). From formulating response plan to carry out effective preparedness activities, arrange and deliver relief materials and carry out effective response such authorities have crucial role to play.

As per the act the Chief District Office (CDO) should lead DDMC whereas the elected mayor of the respective municipality should lead LDMC (The Disaster Risk Reduction and Management Act 2017 2017). And the public servants working in administration, health, education, drinking water, road networks, communication offices at district and municipality levels, and the elected representatives such as deputy mayor, ward chief, ward members should be the active members of these committees (The Disaster Risk Reduction and Management Act 2017 2017). And by virtue of their mandates they should be competent enough to render effective response at the time of disaster.

Precisely saving lives, reducing economic loses and alleviating suffering of the victims are the objectives of the response phase in which activation of emergency operation centers, evacuation of threatened population, carrying out search and rescue operations, management of information, carrying out emergency medical care, opening shelters for displaced population, mass care of the victims and restoring emergency public services are the functions needed to be carried out and lead role should be played by aforementioned local authorities. And to ensure these functions' systematic undertaking of the tasks, utmost cooperation among stakeholders and avoid duplication of effort the 'cluster approach' mechanism should be resorted (IASC 2006). As per NDRF, at national level there should be eleven clusters whereas at local level (district and below), as per the requirement, there may be nine or more clusters (see Table 1). And the officials of the respective ministries, functioning at district level and below, and also the members of DDMC and LDMC, should take lead of the clusters, whereas the international humanitarian organizations (UN, ICRC, and INGO) should remain the assisting agencies and, public and private humanitarian organizations should remain the partners.

Now question arises how effective are these committees and the clusters. Many researches have indicated that the local level disaster response is always problematic in Nepal (Anderson 1995; Smith 2001; Niekerk 2007; Shrestha and Pathranarakul 2018). Robert Piper, a UN Resident and Humanitarian Coordinator in Nepal, once stated that "after five years of working on disaster management in Nepal, I have come to recognize that the addressing Nepal's disaster response is first the governance problem" (Piper 2013) and one reason for such consequence is the lack of knowledge and preparedness amongst the government authorities and elected representatives. Khazai et al. (2018) also stated that the Nepal's local level response mechanism doesn't suffice the need of effective response thus requires more capacity building program.

Various post-disaster reports of mega disasters, such as earthquake of 2015, have also indicated that at times the search and rescue, damage assessment, information management, relief management, and rehabilitation had been problematic (Sanderson and Ramalingam 2015). Jones et al. (2014) claimed that the Nepalese government officials and the elected representatives, especially at the local level, are the protective of their own interest and slow to enact policies to support disaster response initiatives. Gaire et al. (2015) also stated that although Nepal has been participated in many international and national risk management initiatives the ground level policy implementation has always remained problematic. As per Wendelbo et al. (2016) the existing disaster management rules, regulations and framework are neither fully funded nor fully enacted in Nepal.

One of the reasons for such consequence is the preconceived belief of the local authorities that the disaster response is the sole responsibility of the security forces and CDO (Shrestha and Pathranarakul 2018). In practice too during disaster these two entities tend to be heavily engaged carrying out multiple responsibilities whereas other entities remain hardly incorporated. Because of such tendency, empirically, local authorities tend to remain indifference and hesitant to engage in disaster preparedness activities, especially in their own capacity building process. Shrestha and Pathranarakul (2018) stressed that the ignorant of own roles and responsibilities and indecisiveness of local authorities are amongst the reasons for ineffective disaster responses in Nepal.

When it comes to the disaster response competency various researches have argued that the fundamental 
Table 1 Clusters at national and local level

\begin{tabular}{|c|c|c|c|c|c|}
\hline \multirow{3}{*}{$\begin{array}{l}\text { S. } \\
\text { No }\end{array}$} & \multirow[t]{3}{*}{ Name of clusters } & \multicolumn{3}{|l|}{ Government Lead Agency } & \multirow[t]{3}{*}{ Assisting agency } \\
\hline & & \multirow[t]{2}{*}{ National Level } & \multicolumn{2}{|l|}{ Local Level } & \\
\hline & & & District & Municipality & \\
\hline 1 & Health & Ministry of Health and Population & $\begin{array}{l}\text { District Health office } \\
\text { District Hospital }\end{array}$ & Health Office & WHO/IFRC \\
\hline 2 & WASH & $\begin{array}{l}\text { Ministry of Water Supply } \\
\text { and Sewage }\end{array}$ & $\begin{array}{l}\text { Water Supply and Sanitation } \\
\text { Division Office }\end{array}$ & Water Supply Office & UNICEF/IFRC \\
\hline 3 & Emergency Shelter & $\begin{array}{l}\text { Ministry of Urban } \\
\text { Development }\end{array}$ & $\begin{array}{l}\text { Division Office of Urban } \\
\text { Development and Building } \\
\text { Construction }\end{array}$ & Office of the Mayor & IFRC/UN HABITAT/IFRC \\
\hline 4 & Food Security & $\begin{array}{l}\text { Ministry of Agriculture and } \\
\text { Livestock Development }\end{array}$ & $\begin{array}{l}\text { Agriculture Knowledge } \\
\text { Center }\end{array}$ & Agriculture Office & WFP/FAO/IFRC \\
\hline 5 & Nutrition & Ministry of Health and Population & District Public Health Office & Health Office & UNICEF \\
\hline 6 & $\begin{array}{l}\text { Camp Coordination } \\
\text { and Camp management }\end{array}$ & Ministry of Rural Development & $\begin{array}{l}\text { Division of Rural Development } \\
\text { and House Construction }\end{array}$ & Office of the Mayor & IOM \\
\hline 7 & Protection & $\begin{array}{l}\text { Ministry of Women, Children } \\
\text { and Senior Citizen }\end{array}$ & $\begin{array}{l}\text { District Office of Women and } \\
\text { Children }\end{array}$ & $\begin{array}{l}\text { Office of Woman } \\
\text { and Children }\end{array}$ & UNHCR/UNICEF/UNFPA \\
\hline 8 & Early Recovery & $\begin{array}{l}\text { Ministry of Federal Affairs and } \\
\text { General Administration }\end{array}$ & - & & UNDP \\
\hline 9 & Education & $\begin{array}{l}\text { Ministry of Education, Science } \\
\text { and Technology }\end{array}$ & District Education Office & $\begin{array}{l}\text { Municipality } \\
\text { Education Office }\end{array}$ & UNICEF/SC \\
\hline 10 & Logistics & Ministry of Home Affairs & CDO's Office & Office of the Mayor & WFP \\
\hline 11 & Emergency Communication & $\begin{array}{l}\text { Ministry of Communications } \\
\text { and Information Technology }\end{array}$ & CDO's Office & Office of the Mayor & WFP \\
\hline 12 & Search and Rescue & - & CDO's Office & Office of the Mayor & \\
\hline
\end{tabular}

(Source MoHA and MoFALD)

knowledge, disaster response preparedness and the responder's perception are the three primary pillars (Barsky et al. 2007). Mendis et al. (2007) had argued that the knowledge is the fundamental resource to enhance a function intelligently and if applied properly can provide a driving force for the action (Sallis and Jone 2002). Therefore special attention should be given to raise the knowledge and expertise of such local bodies so that they can prepare public services to function at the time of crisis (National Research Council 1991). In that sense knowledge on the protocols of disaster management cycle, structural framework, legal provision, role and responsibility of various agencies, aspect of coordination, command control and communication, etc. is imperative for the government official and elected representative functioning at the local level.

Perception is a form of cognition on which conceptual knowledge and primary form of awareness rely upon (Efron 1969). Penrose (2000) has stated that perception has the potential to influence the extent to which someone is willing to engage in disaster management. Somehow perception is also a force multiplier to influence the action of an individual. Since perception is a view and interpretation based on belief, experience and understanding help to gauge the level of competency of an individual in disaster response (Wolf and Moser 2011).
Similarly, preparedness activity is the most vital element for competency building process (Drabek and Hoetmer 1991). It helps to develop operational capabilities and helps to facilitate effective response at the time of disaster (Drabek and Hoetmer 1991). Mileti (1991) has stated that the effective preparedness and response help to save a life, reduce injury, limit property damage and minimize all sort of disruption at the time of disaster. Preparedness also helps to establish responsibility, identify function and resource, and increases inter-organizational coordination and communication which are the typical problems at the time of crisis at the local level (Heide 1989).

Periodic training, exercise, and rehearsal are the prerequisites for robust preparedness (McEntire and Myers 2004). Such activity gives the responder a platform to design effective, realistic and coordinated planning that ultimately helps to reduce duplication of effort when multiple stakeholders exert holistic effort at the time of disaster (ICRC 2000; Ingrassia et al. 2014). Precisely training helps to impart disaster-related knowledge to a responder whereas exercise and rehearsal help him to test his applicability of that knowledge and planning capability (Perry and Peterson 1999; Drabek and Hoetmer 1991).

Unfortunately in Nepal, the academic study of 'disaster response' discipline has remained in shadow till date (Ghimire 2018). It is because the research sphere has 
been heavily dominated by 'pre disaster risk reduction and mitigation'. Implicitly this tendency has allowed the existing deficiencies of the disaster response venture to remain stay put or even exacerbate. In such a scenario, this research is instrumental. This paper has investigated the prevailing disaster response competency of local authorities keeping their fundamental disaster management knowledge, response preparedness and disaster response perception at nexus and dug out the prevailing gaps. And for the reason followings questions have been set as the research questions.

1. Do the disaster management fundamental knowledge, disaster response preparedness and disaster response perception of the local level government officials and elected representatives warrant an effective response at the time of disaster?

2. What are the prevailing gaps in present disaster response competency building process of local authorities? And what are the means to plug them?

\section{Methodology}

\section{Research overview}

The study was derived from field research adopting a quantitative method. Collection of primary data and their analysis was carried out to investigate the disaster management knowledge, perception and preparedness of the study participants. Government officials-administrators and public servants- working at district and municipality, and elected representative of municipality were the focused study group, since they are the members of DDMC and LDMC and have leading role to play at the time of disaster response.

A set of questionnaire that is cognitive to answer was designed for the survey. While designing the question consideration was given to ask fundamental and generic issues imperative for all DDMC and LDMC members. Consideration was also given to avoid complication in the understanding of the questions since the DDMC and LDMC members tend to be from various governmental departments with different responsibilities. Besides various disaster management literature, binding and nonbinding national and international documents, policy papers, directives, and SOPs were studied in due process of research.

\section{Sample population}

Adopting purposive-sampling altogether 149 officials from thirteen districts, who should be the part of local level disaster response mechanism, were selected for data collection (see Fig. 1) (Barbour 2008). Consideration was given to include study participants from terai and mountain regions, since both are most prone to disasters. Unable to include study participants from Far East and Far West regions is one of the limitations of this study.

The selected study participants suppose to be the members of DDMC and LDMC were from two categories- the government official and the local elected representative. Eighty participants were the government officials i.e. public servants and bureaucrats working at the district level and municipality and 69 participants were the elected representatives i.e. mayors, deputy mayors, ward chief and ward members of the municipality, rural municipality. The choice of participants was driven by the research questions, not by a concern of representativeness.

\section{Research design}

For survey all together 24 closed-ended Self Administered Questions (SAQ) waere designed (Ronan et al. 2010; Kuroiwa 1993 and Arya 1993). These questions were divided into three categories. The first category comprised of seventeen questions to investigate study participants' disaster response awareness. The knowledge about the different types of disasters occurring in the country and the fundamental knowledge of disaster response mechanism, system and chain of command were the questions here. The second category comprised four questions to investigate their perception in disaster response capacity building. Whether disaster response capacity of local authority including security forces should be enhanced, is capacity building endeavor equally important for them and does the country needs a separate entity for disaster management are the part of the questions in this category. Similarly, the third category comprised of three questions to investigate their preparedness level that is their involvement in any disaster management training, exercise and whether their respective offices have disaster response Standing Operating Procedure (SOP) or not.

In overall three types of closed-ended SAQs was designed. First was Likert Scale questions, the second was 'check all that applies' type and third was Dichotomous questions. During analysis, all the replies were re-coded into the ordinal scale.

To facilitate the understanding of the participants, the questions were designed in Nepali script and were translated into the English language during analysis. Enumerators that are well knowledgeable in disaster management discipline were utilized to facilitate the overall survey process.

The survey was conducted in an interview style. Averagely 20-30 minutes took for each participant to complete the question-answer process.

\section{Method of analysis}

Basically, the inferential analysis method was adopted to investigate the disaster response competency of a local 


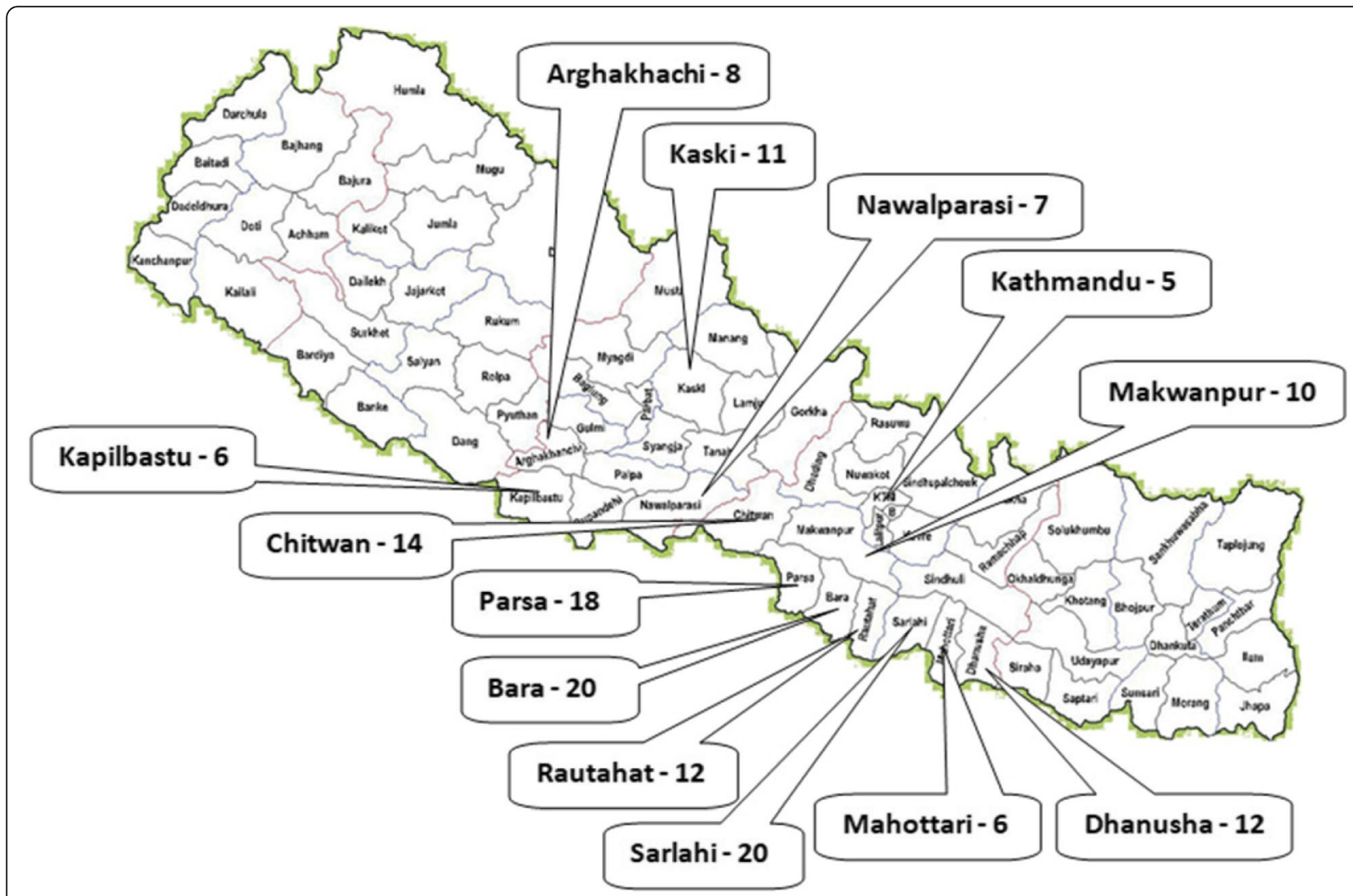

Fig. 1 Study participants and districts

government official and elected representative. Three key independent variables-knowledge, perception, and preparedness-and two dependent variables- government official and elected representative - were taken into consideration during analysis.

The Cross Tabulation and Kruskal-Wallis Test were adopted to study the interactions between dependent and independent variables. Their results were illustrated through the bar graph and comparison table. For detail analysis, the results of the graphic rating scale and numeric rating scale were rephrased into nominal scale. For example, in an issue, if a respondent participant replies 'Strongly agree' and 'Agree' then he/she is considered as well informed. The relationship between independent and dependent variables was examined through Cross Tabulation and their statistically significant was verified through the Kruskal-Wallis Test. The SPSS 16.0 software was used for the analysis process.

\section{Result and analysis}

\section{Fundamental knowledge of disaster management}

At first, eight questions were asked to the study participants' knowledge on disaster vulnerability in Nepal. $48.9 \%$ of the participants considered flood and inundation as the most vulnerable disasters in the country.
Subsequently, 39.7\% participants considered earthquake, $35.5 \%$ participants considered fire, $17.5 \%$ participants considered landslide, and 16\% of the participants considered draught as vulnerable. Similarly, tsunami, avalanche, and volcano were considered by $5 \%, 3 \%$ and $1.9 \%$ of the participants subsequently (see Fig. 2). But as per the data derived from MoHA fire is the most vulnerable disaster in Nepal. In last 54 years 5837 fire incidents had occurred. However as per human loss the earthquake is the most devastating (see Fig. 2). Then there comes the flood and inundation, and landslide as per the frequency of occurrence. But landslide has killed more people than flood and inundation. Similarly, draught and avalanche had occurred only 126 and 125 times. And there is no history of volcano occurrence in Nepal. (see Fig. 3).

Another nine questions were asked to examine the disaster management knowledge of the study participants. The analysis reveals that around $50 \%$ of the participants were not aware of five issues amongst nine. Unfortunately, only $44.3 \%$ of the participants replied that MoHA is the leading agency for disaster management in Nepal.

Indeed this is a dismaying fact that $55 \%$ of the participating local officials were not found aware of this basic fact. Similarly, $55 \%$ of the participants replied that NEOC falls under MoHA. Here also $45 \%$ of the 


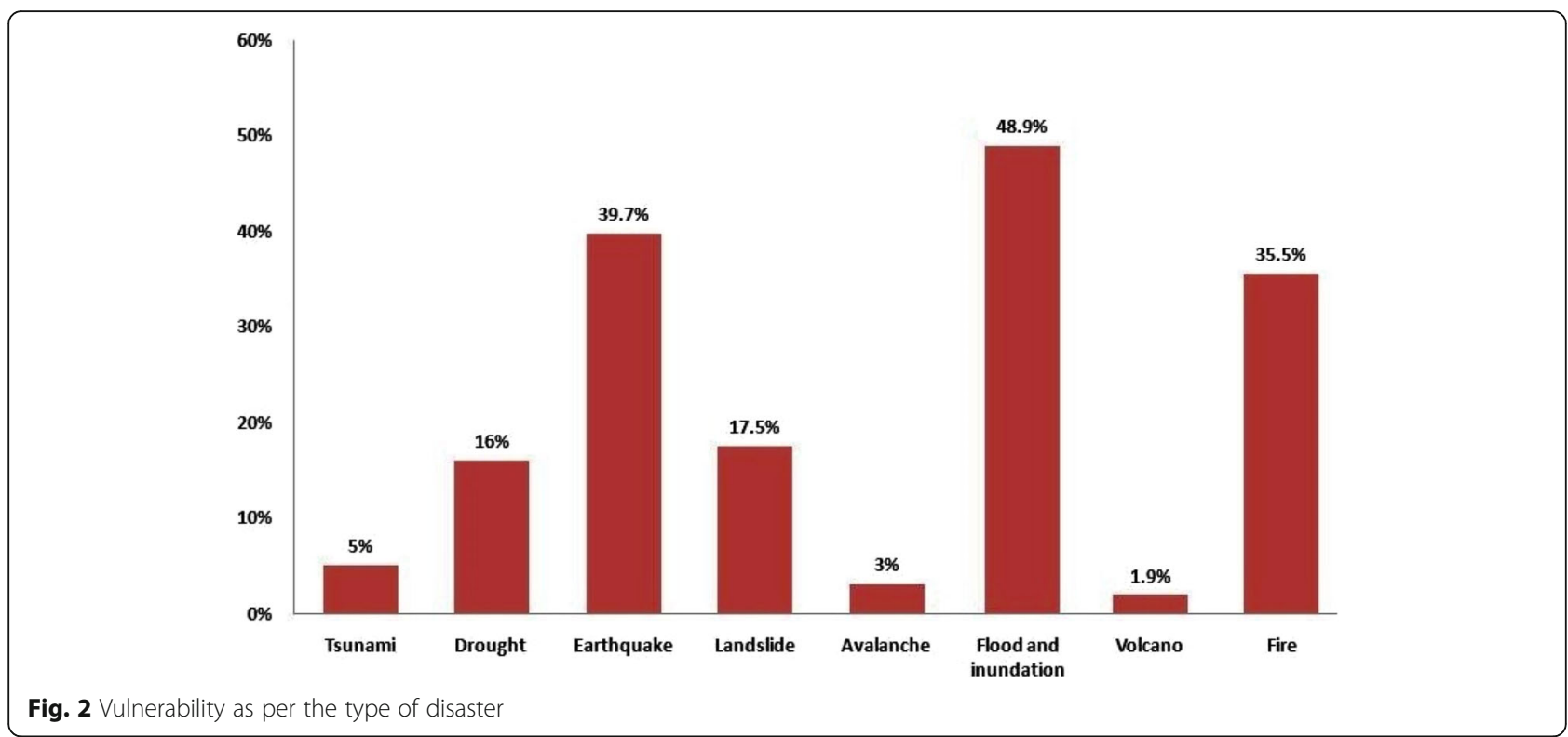

participants lacked the knowledge. And only $51 \%$ of participants are convinced that the LDMC should conduct disaster mock drill at the local level. Another 49\% of the participants didn't have knowledge that the Disaster Risk Reduction and Management Act 2017 has mandated local government to strengthen the local-level response capability.

Around 28\% of the participants didn't know that there are three tiers of disaster management committees in the country. Similarly, another $90 \%$ of the participants didn't know that the DDMC doesn't have authority to declare disaster emergency at the local level. It is the responsibility of the central government and DDMC can only recommend declaring disaster emergency to its higher chain of command.
Only $22 \%$ of the participants knew that the elected municipal chairperson should lead LDMC. 35\% of the participants identified another basic fact that the local government is the most responsible body to manage disaster in the country. Dismayingly, $65 \%$ of the participants were found unknown to this reality (see Fig. 4). In overall, the study participants' awareness in disaster vulnerability and disaster management fundamental knowledge is not convincing. Huge gap prevails in this context.

\section{Perception on disaster response}

Four questions were asked to study the perception of the study participants on disaster response. Encouragingly all the responses were convincing. $90 \%$ of the

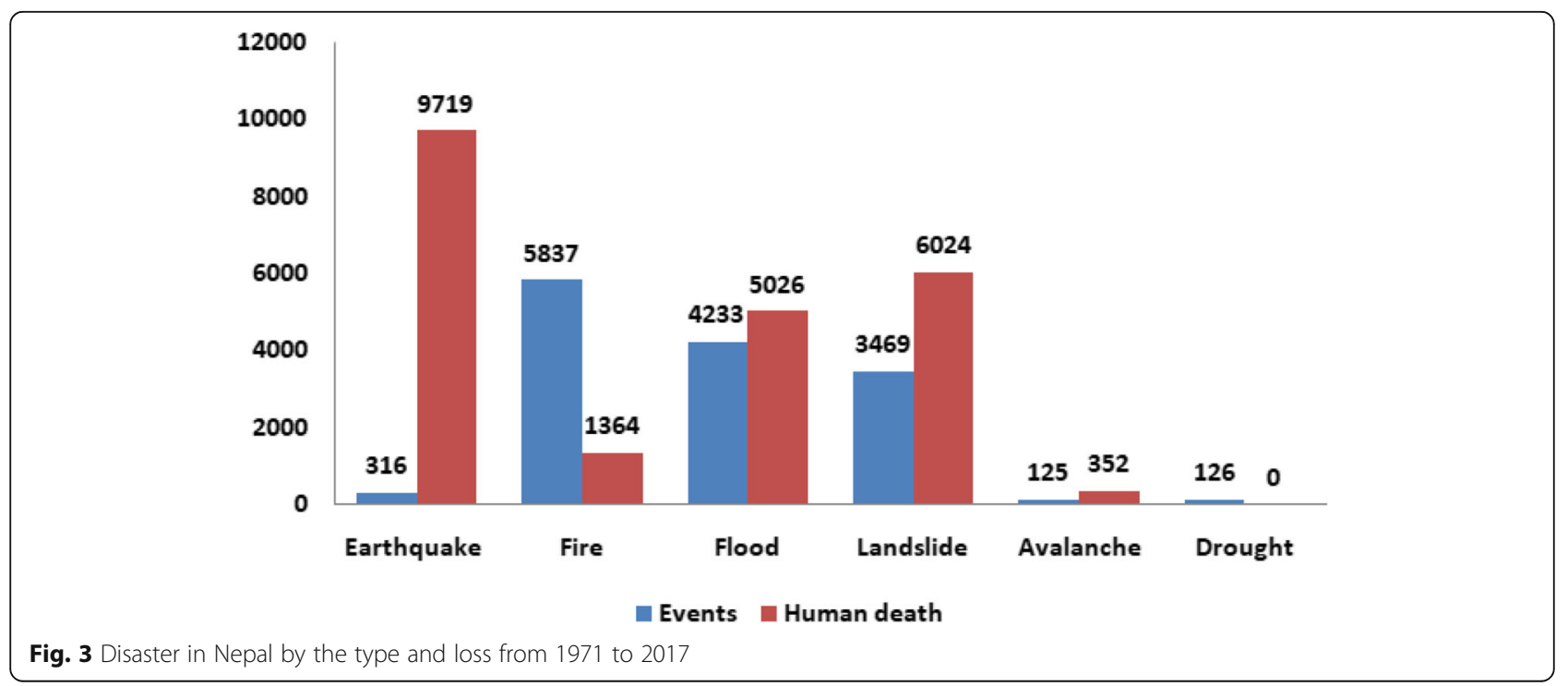




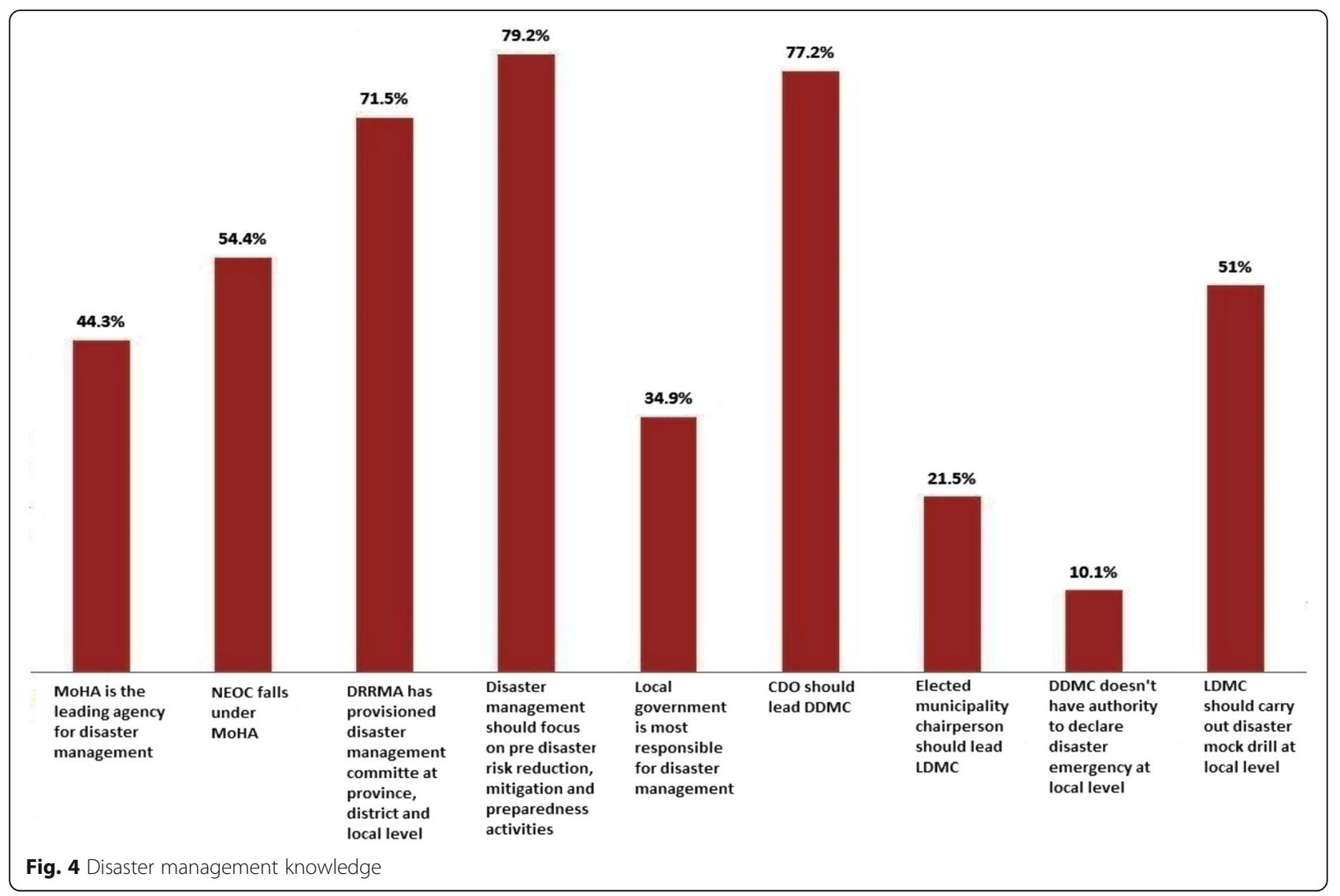

participants agreed that the local level disaster response capacity needs enhancement. Around $80 \%$ participant also agreed that the search and rescue capacity of the security forces needs improvement since they are the prime tool. And around $60 \%$ of the participants agreed that the local elected representative and government official should take part in a disaster response exercise (see Fig. 5). Similarly, $58 \%$ of the participants agreed that there needs a separate ministry in the country to look after disaster management venture.

\section{Disaster response preparedness}

Considering training and exercise as the fundamental curricula to enhance disaster response preparedness, when asked, $44 \%$ of the participants replied that they have partaken in formal disaster management training in their

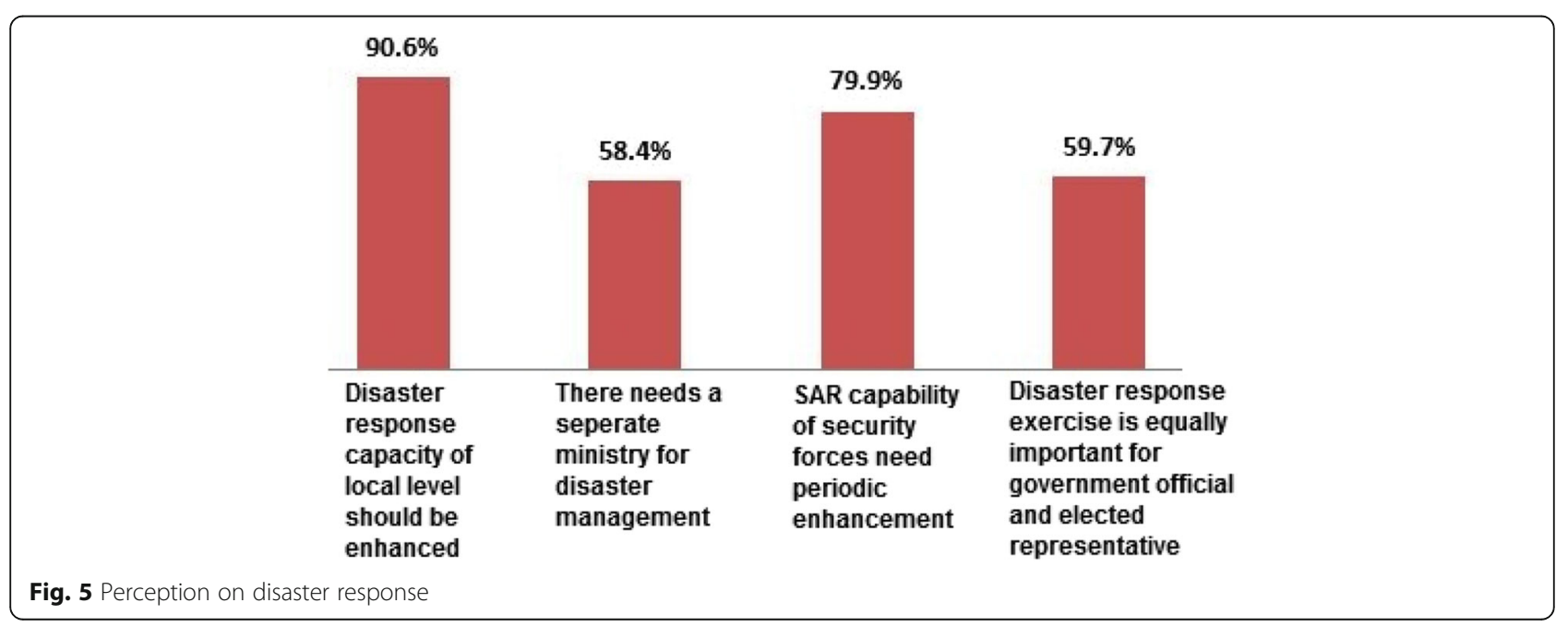




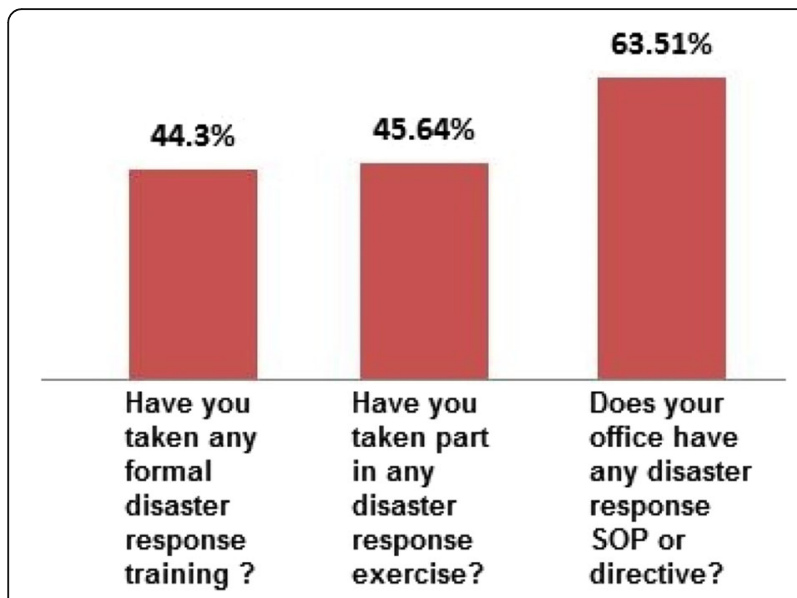

Fig. 6 Disaster response preparedness

career. Another $46 \%$ of the participants replied that they have participated in some sort of disaster response exercise (see Fig. 6). Whereas more than $50 \%$ of the participants were found neither trained nor exercised in disaster response.

In the part of emergency plan $64 \%$ of the participants replied that their offices have prepared Standing Operating Procedure (SOP) or directive for emergency response purpose. Whereas in the public service offices where $36 \%$ of the participants functioning do not exist any emergency response plan. This result shows that the disaster response preparedness of study participants is not satisfying.

\section{Comparative study of the knowledge, preparedness and perception of the government official and elected representative}

During comparative study differences were found in the result of knowledge, perception and preparedness of the government officials and elected representatives. Although the elected representatives have better understanding in disaster consequences and their vulnerability (see Fig. 7) their fundamental knowledge is lesser in most of the cases compared to the government officials. Government officials were found slightly knowledgeable in fundamental issues (see Fig. 7). In part of perception too the government officials have better opinion than the elected representatives (see Fig. 7). But in the part of preparedness the elected representatives were found more trained than government officials and their offices have better SOP preparation compared to the government officials (Fig. 7).

But, at the end, this result has raised a question in the quality of preparedness activities. Although the elected representatives are more engaged in training their fundamental knowledge is not better than government official neither they have better perception.
Statistical analysis: consequence of the nature of service (government official vs political representative) in competency

Since, a government official is a bureaucrat hired by the government to work for the public sector where as political representative is elected by the people to represent them in a legislature or government their nature of service is different. To test whether such difference in nature of service makes any statistical relationship in their disaster response competency or not Kruskal- Wallis test has been carried out. And the result shows that the difference in nature in service doesn't make any statistically significant difference in their knowledge and preparedness. It is because in most of the cases of these two variables the $p$ values are over $0.05(p>$ 0.05) (see Table 2). Only in perception statistical significant has been observed. In three cases out of four the $\mathrm{p}$ values are less than $0.05(p<0.05)$ (see Table 2). Since the nature of service has only statistical relationship in perception doesn't have statistical relationship in overall competency.

\section{Correlation analysis among knowledge, perception and preparedness}

The result of Pearson Correlation shows that the knowledge is significantly correlated with perception and preparedness since the $p$ values are less than $0.05(p<0.05)$. Whereas perception and preparedness do not have any significant correlation as their $\mathrm{p}$ values are over 0.05 $(P>0.05)$ (see Table 3$)$. This shows that knowledge is the foundation of perception and preparedness factors since the increment in knowledge also leads to the enhance the perception and preparedness.

\section{Discussion}

The findings reveal that the disaster response competency of the local authorities in Nepal is not enough to render effective response. The prevailing disaster response knowledge and preparedness of the government official and elected representative is deficit. Such tendency ultimately weakens the overall local level disaster response mechanism of the country.

As per Bendimerad (n.d.) the weakness in the disaster response knowledge in local authority ultimately weakens the overall disaster management mechanism since they lack proactivity to work for the venture. Similarly, Christensen (1985) also argued that incompetency, because of lack of knowledge and preparedness, is a thorny problem in disaster response planning and policymaking. Unfortunately, today only 83 out of 753 local governments have formed their disaster management committee whereas formulation of disaster management committee is indeed mandatory as per The Disaster Risk Reduction and Management Act 20172017 (MoHA 2019). Similarly, only 45 
= Gvernment official Elected representative

Vulnarability as per the type of disaster

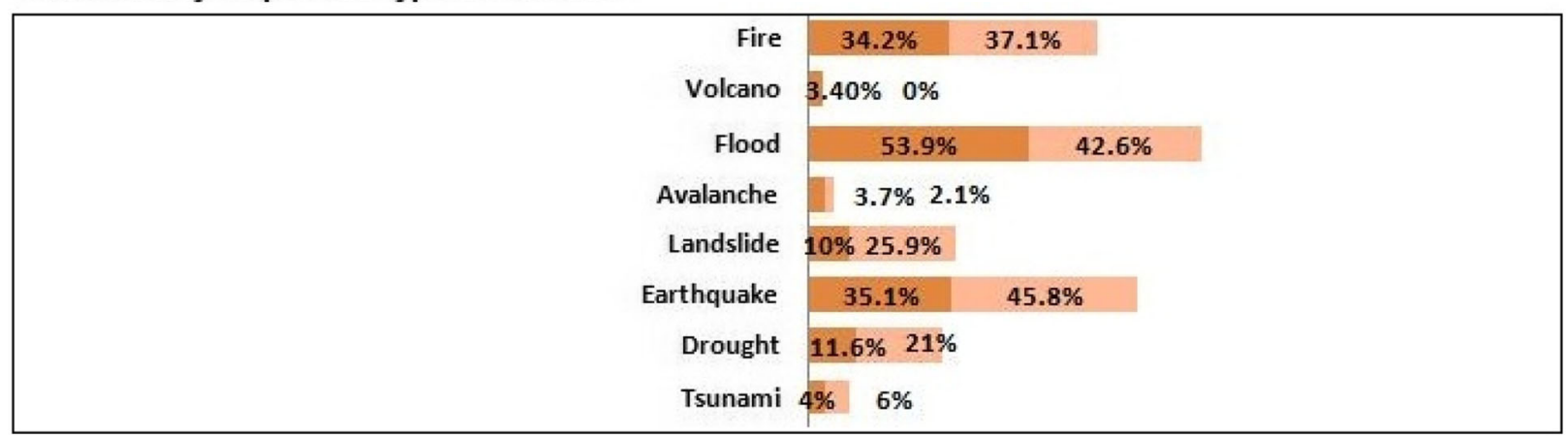

\section{Disaster management knowledge}

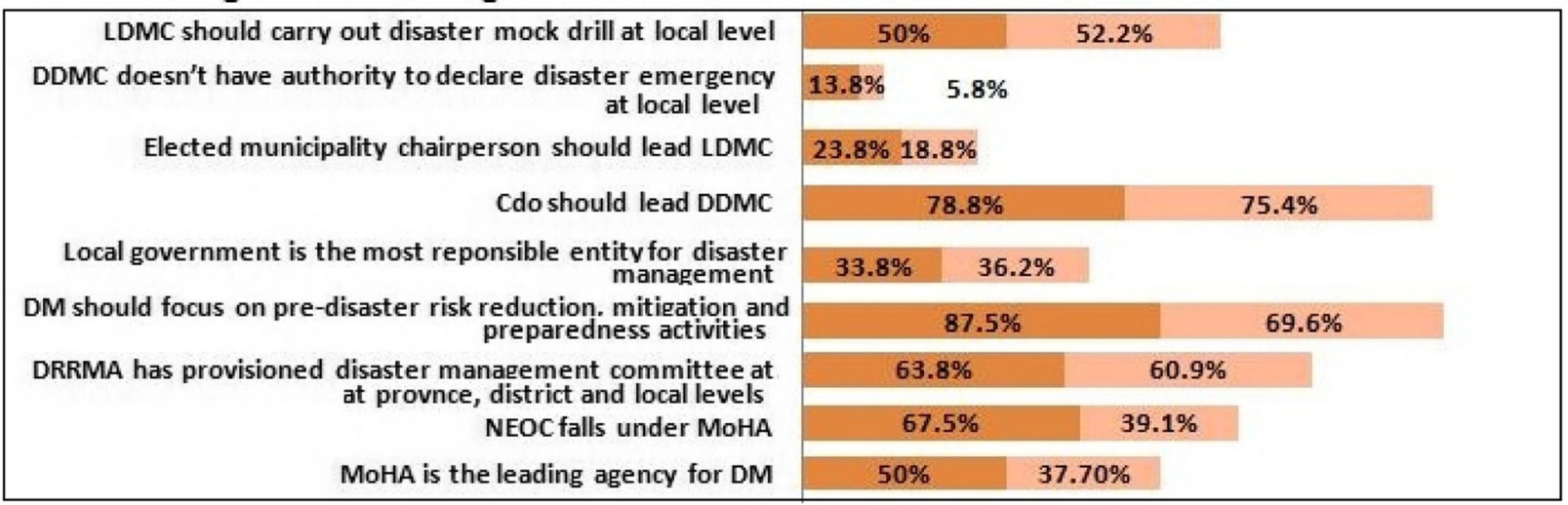

\section{Perception on disaster response}

\begin{tabular}{|c|c|c|c|}
\hline \multirow{4}{*}{$\begin{array}{l}\text { Disaster response exercise is equally important for } \\
\text { government official and elected representative } \\
\text { SAR capability of security froces need periodic enhancement } \\
\text { There needs separate ministry for disaster management } \\
\text { Disaster response capacity of local level should be enhanced }\end{array}$} & 61.29 & \multicolumn{2}{|c|}{$58 \%$} \\
\hline & \multicolumn{2}{|c|}{$86.2 \%$} & $72.5 \%$ \\
\hline & $48.8 \%$ & $69.6 \%$ & \\
\hline & \multicolumn{2}{|c|}{$92.5 \%$} & $88.4 \%$ \\
\hline \multicolumn{4}{|l|}{ Disaster response preparedness } \\
\hline \multirow{3}{*}{$\begin{array}{l}\text { Does your office have any disaster response SOP or directive } \\
\text { Have you taken part in any disaster response exercise } \\
\text { Have you taken any formal disaster response training }\end{array}$} & $57 \%$ & \multicolumn{2}{|c|}{$71 \%$} \\
\hline & $50 \%$ & $40.6 \%$ & \\
\hline & $40 \%$ & $49.3 \%$ & \\
\hline
\end{tabular}

Fig. 7 Comparative study of knowledge, perception and parparedness

municipalities have their disaster management policy and plan at hand (MoHA 2019). And such lethargy is the result of not other than the incompetence of local authorities which is implicitly further exacerbating the communities' disaster vulnerability.

In the part of perception the findings were much encouraging. Despite such weaknesses in knowledge and preparedness, the local authorities have the positive feeling that they should take part in disaster response operations and capacity building process. Such positivity will definitely catalyze the competency if the response capacity is enhanced properly. But unfortunately the government is lacking from grasping this opportunity.

Today the lethargic disaster response capacity building process is the direst fissure to result feeble local level disaster response system in the country. The concern ministries-Ministry of Home Affairs (MoHA) and Ministry of Federal Affairs and General Administration (MoFAGA)have been lacking from fulfilling their mandate of enhancing disaster response capacity of local authorities (Local 
Table 2 Statistical significant difference as per the nature of service

\begin{tabular}{|c|c|c|c|c|}
\hline \multirow[t]{2}{*}{ Category } & \multirow[t]{2}{*}{ Particulars } & \multicolumn{3}{|c|}{$\begin{array}{l}\text { Local administration and elected } \\
\text { representative }\end{array}$} \\
\hline & & $\begin{array}{l}\text { Chi-Square } \\
\text { Result }\end{array}$ & df & $\begin{array}{l}\text { Asymp. Sig. (P value) } \\
\text { (2 sided) }\end{array}$ \\
\hline \multirow{9}{*}{$\begin{array}{l}\text { Disaster management } \\
\text { knowledge }\end{array}$} & MoHA is the leading agency for disaster management & 2.278 & 1 & .131 \\
\hline & NEOC falls under MoHA & 12.018 & 1 & $.001^{*}$ \\
\hline & $\begin{array}{l}\text { DRRMA has provisioned disaster management committee } \\
\text { at province, district and local level }\end{array}$ & .131 & 1 & .717 \\
\hline & $\begin{array}{l}\text { Disaster management should focus on pre-disaster risk } \\
\text { reduction, mitigation, and preparedness activities }\end{array}$ & 7.232 & 1 & $.007^{*}$ \\
\hline & $\begin{array}{l}\text { Local government is the most responsible entity for } \\
\text { disaster management }\end{array}$ & .100 & 1 & .751 \\
\hline & CDO should lead DDMC & .241 & 1 & .623 \\
\hline & Elected municipality chairperson should lead LDMC & .529 & 1 & .467 \\
\hline & $\begin{array}{l}\text { DDMC doesn't have authority to declare disaster } \\
\text { emergency at local level }\end{array}$ & 2.588 & 1 & .108 \\
\hline & LDMC should carryout disaster mock drill at local level & .070 & 1 & .791 \\
\hline \multirow[t]{4}{*}{ Perception } & Disaster response capacity of local level should be enhanced & .729 & 1 & .393 \\
\hline & There needs separate ministry for disaster management & 6.607 & 1 & $.010^{*}$ \\
\hline & SAR capability of security forces needs periodic enhancement & 4.379 & 1 & $.036^{*}$ \\
\hline & $\begin{array}{l}\text { Disaster response exercise is equally important for government } \\
\text { official and elected representative }\end{array}$ & 4.519 & 1 & $.034^{*}$ \\
\hline \multirow[t]{3}{*}{ Preparedness } & Have you taken any formal disaster response training & 1.292 & 1 & .256 \\
\hline & Have you taken part in any disaster response exercise & 1.325 & 1 & .250 \\
\hline & Does your office have any disaster response SOP or directive & 3.138 & 1 & .076 \\
\hline
\end{tabular}

${ }^{*} p<0.05$

Government Operation Act 2017 2017; The Disaster Risk Reduction and Management Act 2017 2017). Various literatures have pointed that in Nepal lack of dedicated institution, void of effective training program, void of effective curriculum along with lack of national policy, plan and dedicated resource allocation are the problems stacked in the disaster response capacity building venture.

Table 3 Statistical correlation among knowledge, perception and preparedness

\begin{tabular}{lllll}
\hline & & Knowledge & Perception & Preparedness \\
\hline Knowledge & Pearson & 1 & $.166^{*}$ & $.180^{*}$ \\
& $\begin{array}{l}\text { Correlation } \\
\text { Perception }\end{array}$ & & & \\
& Sig. (2-tailed) & & .043 & .028 \\
& $\mathrm{~N}$ & 149 & 149 & 148 \\
& Pearson & $.166^{*}$ & 1 & $.114^{*}$ \\
& Correlation & & & \\
& Sig. (2-tailed) & .043 & & .167 \\
& $\mathrm{~N}$ & 149 & 149 & 148 \\
Preparedness & Pearson & $.180^{*}$ & $.114^{*}$ & 1 \\
& Correlation & & & \\
& Sig. (2-tailed) & .028 & .167 & \\
& $\mathrm{~N}$ & 148 & 148 & 148 \\
\hline
\end{tabular}

${ }^{*} \mathrm{p}<0.05$
Although the national institutions - Nepal Administrative Staff College (NASC) and Local Development Training Academy (LDTA) along with LDTA's nine training centers in the country- have responsibility to enhance disaster response capacity of the government officials and elected representatives have not been effective since disaster response trainings and curriculum are not getting required priority. The '32nd Basic Administration Training Program 2016/17' can be taken as an example to corroborate this claim. The training program was conducted by the Nepal Administrative Staff College for the fresh recruited government officers that had only two sessions of 40 minutes each for the overall disaster management teaching including disaster response, whereas the program was run for eighty days with altogether 180 sessions. Similarly, another training program at the staff college the Advance Course on Management and Development run for second class government officials (mid-level officer) didn't have a single session for 'disaster management'. Besides staff college have not been running any specific disaster management training for any government officials. Once an officer at Staff College claimed that the disaster management is a well known subject to government officials hence not needed a separate training program. He 
further added that the ad-hoc disaster management curriculum running in various government training programs will suffice the need. Likewise, there is also a void of disaster response capacity building program for the elected representative. For example the three days training package developed by LDTA for elected representatives is more over focused on 'disaster risk management and climate change'. Disaster response training curriculum has not been incorporated in the package. In such a scenario expecting effective response capacity from local authorities is not more than a distant dream.

Another shortfall that has mired the venture is the government's over-reliance tendency on the external support for capacity building of local authorities $(\mathrm{Qu}$ et al. 2012). Experts have claimed that the state's overreliance on NGO/INGO for capacity building initiative is a problem in the long run (Jones et al. 2014). It is because such over-relying tendency incurs challenge to the government since it weakens local ownership and limits commitment, deepens dependency on foreign resource and experts, and weakens rather than builds local institutions and their capacity (Godfrey et al. 2002). In that sense NGO/INGO involvement may be a short term solution in capacity building process but not the permanent means.

Nepal can learn from Japan and Bangladesh in the context of governments' disaster response capacity building process. In Japan, the Disaster Management Bureau, that comes under the Cabinet Office, headed by the Honorable Prime Minister, runs Disaster Reduction Specialist Training for local authorities on regular basis (Cabinet Office 2015). Similarly, every year, the Central Department Management Council determines the Comprehensive Disaster Management Drill Framework which is exercised nationwide by local authorities on Disaster Preparedness Day (1st September) (Cabinet Office 2015). Likewise, in Bangladesh the Disaster Management Bureau, under the Ministry of Disaster Management and Relief, function as catalyst agency for organizing systematic training programs for local authorities from national down to local level (Haque and Uddin 2013).

Similarly, many other countries have established dedicated training institutions that are completely dedicated to delivery disaster-related training to the local authorities. The following are some examples of the training institute and their disaster preparedness training programs. (see Tables 4 and 5).

Indeed at present devising a national policy on disaster response capacity building, establishment of a dedicated training institution and designing standard training curriculum are the urgent needs of the country (MoHA 2009). Besides, to mainstream public services into the sphere of effective disaster response,
Table 4 Government institutions for the disaster management training

\begin{tabular}{ll}
\hline Country & Institution \\
\hline USA & $\begin{array}{l}\text { National Training and Education Directorate } \\
\text { Emergency Management Institute of Federal Emergency } \\
\text { Management Agency and Center for Domestic } \\
\text { Preparedness in Department of Homeland Security }\end{array}$ \\
Australia & $\begin{array}{l}\text { Australian Emergency Management Institute } \\
\text { Singapore }\end{array}$ \\
Korea & Singapore Civil Defense Academy \\
India & National Disaster Management Institute \\
Philippines & Disaster Risk Reduction and Management Training Institute \\
Thailand & $\begin{array}{l}\text { Thailand's National Disaster Prevention and Mitigation } \\
\text { Academy }\end{array}$ \\
\hline
\end{tabular}

policy should be made that each and every government-run training program should include disaster management training package in their curriculum. This will definitely help to plug the existing gap of disaster response competency of local authorities.

Table 5 Disaster management trainings for the government officials in various countries

\begin{tabular}{|c|c|c|}
\hline Country & Name of Institution & $\begin{array}{l}\text { Training Courses offered } \\
\text { on Disaster Management } \\
\text { for government official }\end{array}$ \\
\hline Afghanistan & $\begin{array}{l}\text { Kabul University, } \\
\text { Department of } \\
\text { Environment Protection } \\
\text { and Disaster Management }\end{array}$ & $\begin{array}{l}\text { Training for government } \\
\text { officials on different DRR } \\
\text { subjects }\end{array}$ \\
\hline Bhutan & $\begin{array}{l}\text { Department of Disaster } \\
\text { Management, Ministry of } \\
\text { Home and Culture Affairs }\end{array}$ & $\begin{array}{l}\text { Preparedness and } \\
\text { Mitigation Department } \\
\text { of DDM, through its } \\
\text { Education and Awareness } \\
\text { Unit is responsible for } \\
\text { building capacities of } \\
\text { national and sub national } \\
\text { institutions (sector/ } \\
\text { Dzongkhag/ Thromde/ } \\
\text { Dungkhag and Gewog) }\end{array}$ \\
\hline China & $\begin{array}{l}\text { National Institute of } \\
\text { Emergency Management, } \\
\text { Chinese Academy of } \\
\text { Governance }\end{array}$ & $\begin{array}{l}\text { Training of senior officials } \\
\text { in disaster management } \\
\text { from national ministries } \\
\text { and provinces. Implemented } \\
\text { Sino German collaborative } \\
\text { training program }\end{array}$ \\
\hline Indonesia & $\begin{array}{l}\text { Training and Education } \\
\text { Unit, Disaster Management } \\
\text { Training Center, Indonesia } \\
\text { National Disaster } \\
\text { Management Agency }\end{array}$ & $\begin{array}{l}\text { Training courses for officials } \\
\text { from central, provincial and } \\
\text { district disaster management } \\
\text { agencies. }\end{array}$ \\
\hline Pakistan & $\begin{array}{l}\text { National School of } \\
\text { Public Policy }\end{array}$ & $\begin{array}{l}\text { Lessons and simulation } \\
\text { exercise on disaster } \\
\text { management are part of } \\
\text { the training modules of } \\
\text { academies responsible for } \\
\text { entry level and in service } \\
\text { training of civil servant }\end{array}$ \\
\hline
\end{tabular}


Undeniably, disaster response is a bottom-up approach and local authorities are the nexus of the overall venture. Therefore rather than relying on foreign aid, the state shouldn't hesitate to invest own national resources on regular basis to enhance their capacity. Indeed, a dollar invested today in disaster preparedness will save six dollars tomorrow during response. And for a poor country like Nepal resource management during post disaster reconstruction is another disaster.

\section{Conclusion}

Today the disaster response knowledge and preparedness of Nepalese government officials and local authorities is dearth. Such dearth doesn't ensure effective response at the time of crisis. The lack of government's effort to enhance their capability is the ultimate cause of the problem.

Similarly over reliance on foreign support for capacity building process is another hurdle that has garnered lethargy amongst national authorities along with crippled the national capacity building mechanism. Such support can only be a short term solution. For ultimate solution, there requires a national policy, national capacity building institution, regular flow of national resources, and standard training program and curriculum. Besides, making disaster response training and curriculum mandatory in each and every government run training program for local authorities is also helpful to unfasten the tightened knot of capacity building.

There is no denial at any level that Nepal needs an effective local level disaster response mechanism and that is only achievable if the disaster response competency of local authorities is enhanced properly. However to achieve that object the overall disaster response capacity building process of the country needs revitalization and resuscitation from a newer dynamic.

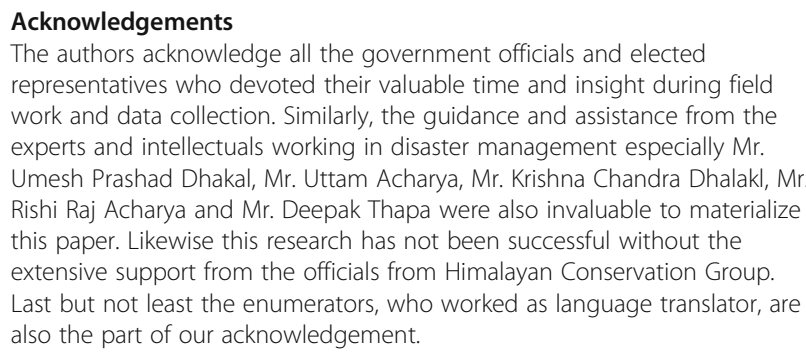
representatives who devoted their valuable time and insight during field work and data collection. Similarly, the guidance and assistance from the experts and intellectuals working in disaster management especially Mr. Umesh Prashad Dhakal, Mr. Uttam Acharya, Mr. Krishna Chandra Dhalakl, Mr. Rishi Raj Acharya and Mr. Deepak Thapa were also invaluable to materialize this paper. Likewise this research has not been successful without the extensive support from the officials from Himalayan Conservation Group. Last but not least the enumerators, who worked as language translator, are also the part of our acknowledgement.

\section{Authors' contributions}

S B Malla carried out the field investigations. S B Malla, R K Dahal and S Hasegawa developed the research method. S B Malla and R K Dahal wrote the manuscript. All three authors have read and approved the final manuscript.

\section{Funding}

No funding was received for this work.

\section{Competing interests}

The authors declare that they have no competing interest.

\section{Author details}

${ }^{1}$ Graduate School of Engineering, Kagawa University, 2217-20 Hayashi-cho, Takamatsu, Kagawa 761-0396, Japan. ²Budhanilkantha Municiaplity, Ward No. 1, Kathmandu, Nepal. ${ }^{3}$ Central Department of Geology, Tribhuvan University, Kritipur, Nepal. ${ }^{4}$ Kagawa University, Takamatsu, Japan. ${ }^{5}$ Center for Disaster Management Informatics Research, Ehime University, Ehime, Japan.

${ }^{6}$ Himalaya Conservation Group, Kalika Marge, Sanepa-2, Lalitpur, Nepal. 7 Department of Safety Systems Construction Engineering, Kagawa University, 2217-20 Hyashi-cho, Takamatsu City 761-0396, Japan.

Received: 22 November 2019 Accepted: 8 April 2020

Published online: 08 May 2020

\section{References}

Anderson MB (1995) Vulnerability to disaster and sustainable development: a general framework for assessing vulnerability. In: Munasinghe MM, Caroline C (eds) Disaster prevention for sustainable development: Economic and policy issues. The International Bank for Reconstruction and Development / World Bank, Washington, D.C., pp 41-59

Arya AS (1993) Training and drills for general public in emergency response to a major earthquake. Training and education for improving earthquake disaster management in developing countries, UNCRD Meeting Reports Series No. 57, Japan, pp 103-114

Barbour R (2008) Introducing qualitative research: a student guide to the craft of doing qualitative research. Sage, Newcastle

Barsky LE, Trainor JE, Torres MR, Aguirre BE (2007) Managing volunteers: FEMA's urban search and rescue programme and interactions with unaffiliated responders in disaster response. Disasters 31(4):495-507

Bendimerad F (n.d.) Disaster Risk Reduction and Sustainable Development. https://pdfs.semanticscholar.org/7219/29932392f6b5d9bd4861f615d8554 dade5e1.pdf. Accessed 28 Aug 2019

Cabinet Office (2015) White paper disaster management in Japan 2015 Government of Japan, pp 35-64. http://www.bousai.go.jp/kaigirep/hakusho/ pdf/WP2015_DM_Full_Version.pdf. Accessed 2 Sept 2019

Christensen KA (1985) Coping with uncertainty in planning. J Am Plan Assoc 51(1):63-73

Daly P, Ninglekhu S, Hollenbach P, Barenstein JD, Nguyen D (2017) Situating local stakeholders within national disaster governance structures: rebuilding urban neighborhoods following the 2015 Nepal earthquake. Environ Urban 29(2): 403-424

Drabek T, Hoetmer G (1991) Emergency management: principles and practice for local government. International City Management Association, Washington, DC

Efron R (1969) What is perception. In: Cohen R S \& Wartofsky M W (eds) Boston studies in the philosophy of science. Proceedings of the Boston colloquium for the philosophy of science 1966/1968 volume IV. D. Reidel Publishing Company, Dordrecht, p 137

Gaire S, Delgado RC, González PA (2015) Disaster risk profile and existing legal framework of Nepal: flood and land slide. Risk Management Healthcare Policy 8:139-149

Ghimire I (2018) Status of regulatory framework for disaster risk reduction and awareness. Paper presented at the sustainable development goals and disaster risk reduction : reducing the economic loss of disasters, Nepal tourism board, Kathmandu, 30 October 2018

Godfrey M, Sophal C, Kato T, Piseth LV, Dorina P, Saravy T, Savora T, Sovannarith S (2002) Technical assistance and capacity development in an aid-dependent economy: the experience of Combodia. World Dev 30(3):355-373

Haque CM, Uddin MS (2013) Disaster management discourse in Bangladesh: a shift from post-event response to the preparedness and mitigation approach through institutional partnerships. In: John T (ed) Approaches to disaster management - examining of hazards, emergencies and disasters. IntechOpen Limited, London, pp 34-54

Heide EAD (1989) Disaster response: principles of preparation and coordination. The C.V.Mosby Company, St. Louis

IASC (2006) Guidance note on using the cluster approach to strengthen humanitarian response. http://www.globalprotectioncluster.org/_assets/files/ about_us/IASCGN_using_the_Cluster_Approach_to_Stengthen_ Humanitarian_Response_24NOV2006-EN.pdf. Accessed 4 Sept 2019 
ICRC (2000) Introduction to disaster preparedness: Disaster preparedness training programme, participant resource \& learning module. https://www.ifrc.org/ Global/Publications/disasters/all.pdf. Accessed 16 Aug 2019

Ingrassia PL, Foletti M, Djalali A, Scarone P, Ragazzoni L, Corte FD, Fisher P (2014) Education and training initiatives for crisis management in the European Union: a web based analysis of available programs. Prehospital Disaster Medicine 29(4):115-126

Jones S, Oven K, Manyena B, Aryal K (2014) Governance struggles and policy processes in disaster risk reduction: a case study from Nepal. Geoforum 57:78-90

Khazai B, Anhorn J, Burton GC (2018) Reliance performance scorecard: measuring urban disaster resilience at municipality levels of geography with case study application to Lalitpur, Nepal. Int J Disaster Risk Reduction 31:604-616

Kuroiwa JA (1993) Peru's national educational program for disaster prevention and mitigation (PNEPDPM), in training and education for improving earthquake disaster management in developing countries, UNCRD meeting report series no. 57,Japan, pp 95-102

Local Government Operation Act 2017 (2017, October 15). Retrieved from http:// www.chainpurmun.gov.np/sites/chainpurmun.gov.np/files/documents/\%E0\% A4\%B8\%E0\%A5\%8D\%E0\%A4\%A5\%E0\%A4\%BE\%E0\%A4\%A8\%E0\%A5\%80\% E0\%A4\%AF-\%E0\%A4\%B8\%E0\%A4\%B0\%E0\%A4\%95\%E0\%A4\%BE\%E0\%A4\% B0-\%E0\%A4\%B8\%E0\%A4\%9E\%E0\%A5\%8D\%E0\%A4\%9A\%E0\%A4\%BE\%E0\% A4\%B2\%E0\%A4\%A8-\%20\%E0\%A4\%90\%E0\%A4\%A8\%20.pdf

McEntire DA, Myers A (2004) Preparing communities for disasters: issues and processes for government readiness. Disaster Prev Manag 13(2):140-152

Mendis DSK, Karunananda AS, Samaratunga U, Ratnayake U (2007) An approach to the development of commonsense knowledge modeling system for disaster management. The Artificial Intelligence Review 28(2):179-196

Mileti DM (1991) Disasters by design: a reassessment of natural hazards in the United States. Joseph Henry Press, Washington, DC

Miller M, Douglass M (2016) Introduction: decentralizing disaster governance in urbanizing Asia. Habitat International 52:1-4

MoHA (2009) National Strategy for Disaster Risk Management in Nepal 2009. http://un.org.np/sites/default/files/report/2010-08-06-nsdrm-in-eng-2009.pdf. Accessed 3 Oct 2019

MoHA (2015) National Emergency Operation Center: Standing Operating Procedures (SOP). Government of Nepal, Kathmandu.

MoHA (2018a) National position paper on disaster risk reduction and management Nepal. National position paper for the AMCDRR 2018, Ulaanbaatar, Mongolia, 3-6 July 2018. https://www.dpnet.org.np/uploads/files/National\%20Position\%2 OPaper\%202018-09-15\%2018-38-03.pdf. Accessed 15 Oct 2019

MoHA (2018b) Nepal disaster report, 2017: The road to Sendai. Available at http://drrportal.gov.np/uploads/document/1321.pdf. Accessed 1 Sept 2019

MoHA (2019) Nepal Disaster Report 2019. Available at http://drrportal.gov.np/ uploads/document/1594.pdf. Accessed 5 Oct 2019

National Research Council (1991) A safer future: reducing impact of natural disasters. The National Academies Press, Washington, DC, pp 17-19

Niekerk DV (2007) Local government disaster risk management. In: Van der Gerrit W (ed) Municipal management: serving the people. Juta and Company Ltd, Cape Town, p 234

Penrose JM (2000) The role of perception in crisis management. Public Relat Rev 26(2):155-171

Perry RW, Peterson DM (1999) The impact of disaster exercise on participants. Disaster Prev Manag 8(4):241-254

Piper R (2013) A perfect storm of earthquake and poor governance could cripple Nepal. The Guardian, 12 January https://wwwtheguardiancom/ commentisfree/2013/jan/12/perfect-storm-earthquake-cripple-nepal. Accessed 18 Oct 2019

Qu G, Liu SM, Sun G (2012) Capacity Assessment for Nepal- Urban Search and Rescue, Sustainable Training and Resilient Disaster Management. Available at https://www.flagship2.nrrc.org.np/sites/default/files/knowledge/Nepal\%2 0Capacity\%20Assessment\%20Final\%20Report\%20.pdf. Accessed 29 Aug 2019

Ronan K, Crellin K, Johnston D (2010) Correlates of hazards education for youth: a replication study. Nat Hazards 53(3):503-526

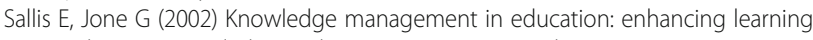
\& education. Routledge Taylor \& Francis Grup, London

Sanderson D, Ramalingam B (2015) Nepal earthquake response: lessons for operational agencies. ALNAP Lessons Paper, London, pp 6-25

Shrestha B, Pathranarakul P (2018) Nepal Government's emergency response to the 2015 earthquake: a case study. Soc Sci 7(8):3

Smith K (2001) Environmental hazards: assessing risk and reducing disasters third edition. Routledge, New York, NY
The Disaster Risk Reduction and Management Act 2017 (2017) Available at https://www.ilo.org/dyn/natlex/docs/ELECTRONIC/106076/129931/F19966042 88/NPL106076\%20Npl.pdf. Accessed 10 Oct 2019

UNDRR (2019) Disaster risk reduction in Nepal: Status report 2019. United Nations Office for disaster risk reduction (UNDRR), Regional Office for Asia and the Pacific, Bangkok https://reliefweb.int/sites/reliefweb.int/files/resources/6823 0_6nepaldrmstatusreport.pdf. Accessed 10 Sept 2019

UNISDR (2005) Hyogo framework for action: 2005-2015: Building the resilience of nations and communities to disasters, UN Office for Disaster Risk Reduction. Available at http://www.unisdr.org/files/1037 hyogoframeworkforactionenglish.pdf. Accessed 20 Sept 2019

UNISDR (2015) Sendai framework for Disaster Risk Reduction 2015-2030, UN Office for Disaster Risk Reduction. Available at https://www.preventionweb. net/files/43291_sendaiframeworkfordrren.pdf. Accessed 25 Sept 2019

Wendelbo M, China FL, Dekeyser H, Taccetti L, Mori S, Aggrawal OA, Savoldi A, Zielonka R (2016) The crisis response to the Nepal earthquake: lessons learned. http://www.eiasorg/wp-content/uploads/2016/02/TheCrisisResponse-to-the-Nepal-Earthquake-_-Lessons-Learned-colour-1pdf. Accessed 17 Oct 2019

Wolf J, Moser SC (2011) Individual understandings, perception, and engagement with climate change: insights from in-depth studies across the world. Advanced Review 2:547-569

\section{Publisher's Note}

Springer Nature remains neutral with regard to jurisdictional claims in published maps and institutional affiliations.

\section{Submit your manuscript to a SpringerOpen ${ }^{\circ}$ journal and benefit from:}

- Convenient online submission

- Rigorous peer review

- Open access: articles freely available online

- High visibility within the field

- Retaining the copyright to your article

Submit your next manuscript at $\boldsymbol{\nabla}$ springeropen.com 